\title{
Isolation and Identification of Pathogenic Gram-Positive Bacteria from Egg Shell of Hen and to See Their Antimicrobial Susceptibility Pattern
}

\author{
Jannatul Fardows ${ }^{1}$, Abu Bakar Siddique ${ }^{2}$, Adneen Moureen ${ }^{3}$, Tasmin Afroz Binte Islam ${ }^{4}$, Nasrin \\ Farhana $^{5}$, Chowdhury Rafia Naheen ${ }^{6}$ \\ Received: September 29, 2015 Accepted: December 12, 2015 \\ doi: http://dx.doi.og/10.3329/jemc.v6i1.26374
}

\begin{abstract}
Background: Food-borne disease is a major public health problem affecting developed as well as developing countries. Inaccurately treated eggs can be one of its causes. So we designed this study to observe the possibility of transmission of pathogenic Gram-positive bacteria from market eggs to the community. Objectives: To identify different Gram-positive bacteria in eggs and to observe their antimicrobial susceptibility. Materials and Methods: This observational study was conducted in the department of Microbiology, Dhaka Medical College, Dhaka. Shells of 150 eggs collected from different markets of Dhaka city were tested. Bacteria were isolated and identified by culture and relevant biochemical tests. Results: Out of $150 \mathrm{egg}$ shells, 120 (80\%) yielded growth of different bacteria. Of them, Staphylococcus spp. were 80 (66.67\%), Streptococcus spp. 8 (6.67\%), Bacillus subtilis 20 (16.67\%) and Bacillus cereus 12 (10\%). Out of 80 Staphylococcus spp., 30 (25\%) were Staphylococcus aureus and 50 (41.67\%) were Staphylococcus saprophyticus. Most of the Gram-positive bacteria were sensitive to ciprofloxacin, ceftriaxone and imipenem. No MRSA and VRSA were found. Conclusion: It can be concluded from this study that Gram-positive bacteria from market eggs may be an important source of infection to the community.
\end{abstract}

Key words: Gram-positive bacteria; Culture; Eggs; Antibiotic susceptibility

J Enam Med Col 2016; 6(1): 15-18

\section{Introduction}

Food-borne illness is a major public health problem and an important cause of diarrheal diseases affecting all developed and developing countries. ${ }^{1}$ Inaccurately treated eggs can cause food-borne illness. ${ }^{2}$ Absence of standard structures and drainage system in the market and relatively high humidity could have contributed to the high microbial growth. ${ }^{3}$ Most retailers do not store eggs in refrigerators, thus the eggs are exposed to weather conditions, resulting in contamination. ${ }^{4}$ In spite of the antibacterial factors, it can be infected with different bacteria such as Salmonella spp., Esch coli, Campylobacter jejuni, Proteus spp., Klebsiella spp. and

different Gram-positive bacteria like Stapylococcus spp., Streptococcus spp., Listeria monocytogens, and Bacillus spp. ${ }^{5}$ Staphylococcus spp. is a major diseaseproducing organism for poultry and approximately $50 \%$ of typical and atypical $S$. aureus strains produce enterotoxins that can cause food poisoning in human being. ${ }^{6}$ Streptococcosis in avian species is worldwide in distribution, occurring as both acute septicemic and chronic infections with mortality ranging from 0.5 $50 \% .{ }^{6}$ Although Bacillus spp. is a saprophytic organism mainly but it also causes food poisoning. ${ }^{5}$

1. Assistant Professor, Department of Microbiology, International Medical College, Gazipur

2. Assistant Registrar, Department of Medicine, Dhaka Medical College, Dhaka.

3. Associate Professor, Department of Microbiology, International Medical College, Gazipur

4. Assistant Professor, Department of Microbiology, Tairunnessa Memorial Medical College, Gazipur

5. Lecturer, Department of Microbiology, Dhaka Medical College, Dhaka

6. Assistant Professor, Department of Microbiology, Kumudini Women's Medical College, Tangail

Correspondence Jannatul Fardows, Email: jannat2026@ gmail.com 
The present study is carried out to isolate the pathogenic Gram-positive bacteria from egg shells of hen by culture and to see their antimicrobial susceptibility pattern.

\section{Materials and Methods}

This observational study was carried out on egg shells of 150 eggs collected from different markets of Dhaka city. The study was done in the department of Microbiology, Dhaka Medical College (DMC), Dhaka from July 2012 to June 2013. Undamaged and clean eggs without fecal contamination and cracks were included in this study.

\section{Sample processing with enrichment}

For each egg, one sterile swab stick was made wet by trypticase soy broth (TSB) and shell swab was taken from the entire surface of the egg and was immediately inoculated in a test tube containing $9 \mathrm{~mL}$ TSB for enrichment. ${ }^{6}$

\section{Isolation of organisms}

After processing, TSB media were incubated at $37^{\circ} \mathrm{C}$ for 24 hours. Then one or two loopful inoculum was streaked on blood agar medium from TSB and again incubated at $37^{\circ} \mathrm{C}$ for 24 hours and examined after 24 hours for visible colony of bacteria. ${ }^{6,7}$ For confirmation of Staphylocoocus spp. subculture was done on mannitol salt agar medium from blood agar medium and incubated at $37^{\circ} \mathrm{C}$ for 24 hours and examined after 24 hours. 8

\section{Identification of organisms}

All the isolated organisms were identified by their colony morphology, staining characters and further confirmed by relevant biochemical tests including catalase test, coagulase test and oxidase test. Staphylococcus aureus from S. saprophyticus were differentiated by novobiocin sensitivity test. Bacillus subtilis were differentiated from B. cereus by mannitol fermentation test. ${ }^{9}$

\section{Antibiotic susceptibility test}

Using Kirby-Bauer modified disc-diffusion technique, antibiotic susceptibility test was performed as described by Clinical and Laboratory Standards Institute (CLSI). ${ }^{10,11}$ Antibiotic dishes of oxacillin $(1 \mu \mathrm{g} / \mathrm{disc})$, vancomycin $(30 \mu \mathrm{g} / \mathrm{disc})$, amoxiclav (amoxicillin and clavulanic acid), (20/100 $\mu \mathrm{g} / \mathrm{disc})$, azithromycin $(15 \mu \mathrm{g} / \mathrm{disc})$, cefixime $(30 \mu \mathrm{g} / \mathrm{disc})$, ceftriaxone
$(30 \mu \mathrm{g} / \mathrm{disc})$, doxycycline $(30 \mu \mathrm{g} / \mathrm{disc})$, erythromycin $(15 \mu \mathrm{g} / \mathrm{disc})$, gentamicin $(10 \mu \mathrm{g} / \mathrm{disc})$, imipenem $(10 \mu \mathrm{g} / \mathrm{disc})$ (Oxoid Ltd. UK) were used. Pure colonies of isolated organisms were emulsified in normal saline and turbidity was matched with $0.5 \mathrm{McF}$ arland turbidity standards. Selected antibiotic discs were placed on inoculated Mueller-Hinton agar medium. These plates were incubated at $37^{\circ} \mathrm{C}$ for 24 hours. Resistant and sensitive bacteria were defined according to CLSI guidelines. $^{11}$

\section{Detection of methicillin resistant Staphylococcus aureus (MRSA)}

Isolated Staphylococcus aureus were screened for methicillin resistance by phenotypic disc diffusion method. Disc diffusion test was performed following Clinical and Laboratory Standard Institute (CLSI, 2010) using oxacillin $(1 \mu \mathrm{g})$ disc. A 0.5 McFarland standard suspension of the isolate was made and inoculated into Mueller-Hinton agar plate by using a sterile swab. Oxacillin disc was applied on plate using sterile forceps. The agar plates were incubated at $37^{\circ} \mathrm{C}$ for 24 hours and diameters of zone of inhibition $<10 \mathrm{~mm}$ indicated oxacillin resistance. $^{12}$

\section{Detection of vancomycin resistant Staphylococcus aureus (VRSA)}

Isolated Staphylococcus aureus were screened for vancomycin resistance by phenotypic disc diffusion method. Disc diffusion test was performed following Clinical and Laboratory Standard Institute (CLSI, 2010) using vancomycin $(30 \mu \mathrm{g})$ disc. A 0.5 McFarland standard suspension of the isolate was made and inoculated into Mueller-Hinton agar plate by using a sterile swab. Vancomycin disc was applied on plate using sterile forceps. The agar plates were incubated at $37^{\circ} \mathrm{C}$ for 24 hours and diameters of zone of inhibition less than $15 \mathrm{~mm}$ indicated vancomycin resistance. ${ }^{12}$

\section{Data analysis}

After compiling data were analyzed using `Microsoft Office Excel 2007` program.

\section{Results}

Out of total 150 egg shells 120 (80.00\%) yielded growth of different Gram-positive bacteria. Among the isolated bacteria Staphylococcus spp. were the most common (66.67\%) organisms and $6.67 \%$ were Streptococcus spp. (Table I). 
According to antimicrobial resistance pattern of Grampositive bacteria isolated from egg shells to different antibiotics, none of the isolates were resistant to ciprofloxacin and ceftriaxone. No MRSA and VRSA were isolated. All (100\%) the Streptococcus spp. were resistant to amoxiclav and doxycycline. All (100\%) the Bacillus spp. were sensitive to imipenem (Table II).

Table I: Frequencies of microbial isolates from egg shells $(n=120)$

\begin{tabular}{|c|c|c|}
\hline Name of the bacteria & Number & Percentage \\
\hline $\begin{array}{l}\text { Staphylococcus spp. } \\
\text { Staphylococcus aureus } \\
\text { Staphylococcus saprophyticus }\end{array}$ & $\begin{array}{l}30 \\
50\end{array}$ & $\begin{array}{l}25.00 \\
41.67\end{array}$ \\
\hline Streptococcus spp. & 8 & 6.67 \\
\hline Bacillus subtilis* & 20 & 16.67 \\
\hline Bacillus cereus & 12 & 10.00 \\
\hline Total & 120 & 100.00 \\
\hline
\end{tabular}

* In this study, B. subtilis were identified in 20 egg shells. Although B. subtilis is non-pathogenic but it can cause allergic manifestations in prolonged exposure and can also cause food poisoning as like $B$. cereus in immunocompromised patients. For this B. subtilis were included in the list of pathogenic bacteria.

Table II: Antimicrobial resistance pattern of isolated bacteria from egg shells to different antibiotics

\begin{tabular}{|l|c|c|c|}
\hline Antimicrobials & $\begin{array}{c}\text { Staphylococcus } \\
\text { spp. }(\mathrm{n}=80)\end{array}$ & $\begin{array}{c}\text { Streptococcus } \\
\text { spp. }(\mathrm{n}=8)\end{array}$ & $\begin{array}{c}\text { Bacillus } \\
\text { spp. }(\mathrm{n}=32)\end{array}$ \\
\hline Oxacilin & $0(0.00)$ & $0(0.00)$ & - \\
\hline Vancomycin & $0(0.00)$ & $0(0.00)$ & - \\
\hline Erythromycin & $30(37.5)$ & $4(50.00)$ & $11(34.35)$ \\
\hline Doxycycline & $70(87.5)$ & $8(100.00)$ & - \\
\hline Ciprofloxacin & $0(0.00)$ & $0(0.00)$ & $0(0.00)$ \\
\hline Ceftriaxone & $0(0.00)$ & $0(0.00)$ & $0(0.00)$ \\
\hline Azithromycin & $0(0.00)$ & $7(87.5)$ & - \\
\hline Cefixime & $40(50.00)$ & $4(50.00)$ & - \\
\hline Amoxiclav & $70(87.5)$ & $8(100.00)$ & - \\
\hline Tetracycline & - & - & $8(25.00)$ \\
\hline Imipenem & - & - & $0(0.00)$ \\
\hline Gentamicin & - & - & $9(28.13)$ \\
\hline
\end{tabular}

\section{Discussion}

Microbial contamination of egg has an important effect on poultry industry and illness from contaminated egg is a serious public health problem around the world. ${ }^{3}$ Though Gram-negative bacteria can contaminate eggs but Gram-positive bacteria are the main culprits to contaminate poultry products. ${ }^{13}$ Gram-positive bacteria can tolerate dry and harsh conditions and are present in dust, soil and feces, which is the major reason of its presence on egg shells. ${ }^{14}$ Food poisoning, and gastroenteritis are the major infections transmitted by feco-oral route in Bangladesh. Eggs are considered as a major source of protein and vitamins for everybody. Eggs are bought from the market and brought to every kitchen irrespective of assessing whether it carries harmful bacteria or not.

Out of 150 eggs collected from different markets, 120 (80\%) egg shells yielded growth of pathogenic bacteria. Another study reported that $95 \%$ egg shells yielded growth of different bacteria from eggs collected from market. ${ }^{7}$ These bacterial contaminations might be from clothes and hands of poultry and market workers, market retailers, use of same tray and environment of the market. ${ }^{15}$ In the developing countries, especially in Bangladesh, inadequate refrigeration even no refrigeration during the market storing can increase the percentage of different bacterial contamination on egg shell.

Out of the 150 shells of eggs collected from market, 30 (20\%) yielded no growth. Abdullah ${ }^{6}$ reported that $5 \%$ of the isolated organisms were fungi and $0.1 \%$ was anerobic bacteria in his study. In the present study, negative results of egg shells might be due to the fact that these samples were contaminated by fungus or anerobic bacteria or any bacteria which were not isolated in routine culture media. If these fungi and anerobic bacteria could be cultured the diagnostic yield would definitely be better. Alternatively, DNA of these organisms which cannot be cultured in routine laboratory media can be detected by PCR. Warm and moist litters, poor condition in the farm houses are the causes of fungi growth and sporulation. ${ }^{16}$

Among the isolated aerobic bacteria, 80 (66.67\%) were Staphylococcus spp. In Iran, relatively higher percentage of Staphylococcus spp. (75\%) was observed. In another study, $28.45 \%$ Staphylococcus spp. was identified. ${ }^{8}$ In this study, 30 (20\%) Streptococcus spp. and 10 (6.67\%) Bacillus spp. were identified. Abdullah ${ }^{6}$ reported that $4.9 \%$ Streptococcus spp. was found in his study, which was lower than what we found in the present study. Contamination is more likely linked with cracked egg, dirty shells and storage in contaminated surroundings. It 
can be contaminated during formation and laying process. ${ }^{14}$ Although Streptococcus and Staphylococcus are present in fecal content but these are the major health concerns causing fever, food poisoning, ocular infection etc. ${ }^{17}$

Drug resistance is a major problem in treating the infectious diseases. In the present study, most of the isolated bacteria showed highest sensitivity to ciprofloxacin and ceftriaxone (100\%). In case of Staphylococcus spp., all (100\%) serotypes were sensitive to oxacillin and vancomycin. Another study reported that $14.25 \%$ Staphylococcus spp. were resistant to oxacillin. ${ }^{18}$

From this study, it can be concluded that eggs may be a source of transmission of different Gram-positive bacteria from market to the community. Early detection and proper hygienic practice should be maintained in handling and marketing eggs by the farm handlers and retailers to prevent spread of infection of different Gram-positive bacteria to the community. Ceftriaxone and ciprofloxacin are the most effective drugs against Gram-positive bacteria isolated from market eggs.

\section{Acknowledgement}

This work was supported by the Department of Microbiology, Dhaka Medical College, Dhaka.

\section{References}

1. Akbar A, Anal AK. Zinc oxide nanoparticles loaded active packaging, a challenge study against Salmonella typhimurium and Staphylococcus aureus in ready-to-eat poultry meat. Food Control 2014; 38: 88-95.

2. Musgrove MT, Northcutt JK, Jones DR, Cox NA, Harrison MA. Enterobacteriaceae and related organisms isolated from egg shells collected during commercial processing. Poult Sci 2008; 87(6): 1211-1218.

3. Safaei G, Jalali M, Hosseini A, Narimani T, Sharifzadeh A, Raheim E. The prevalence of bacterial contamination of table eggs from retail markets by Salmonella spp., Listeria monocytogenes, Campylobacter jejuni and Esch coli in Shhrekord, Iran. Jundishapur J Microbiol 2011; 4(4): 249-253.

4. Addey S, Ansah TGSK, Dzoagbe GA, Teye S, Danquah JK. Microbial quality of table eggs sold on selected markets in the Tamale Municipality in the Northern Region of Ghana. Res Rural Dev 2009; 21: 8.

5. Mahdavi M, Jalali M, Safaei HG, Shamloo E. Microbial quality and prevalence of Salmonella and Listeria in eggs. Int J Envior Health Eng 2012; 1: 6.

6. Abdullah IN. Isolation and identification of some bacterial isolates from table egg. J Net Sci 2010; 3(2): 1025-1031.

7. Loongyai W, Promphet K, Kangsukul N, Noppha R. Detection of Salmonella in egg shell and egg content from different housing systems for laying hens. World Acade Sci Eng Technol 2010; 4: 41.

8. Siriporn C, Ali A, Anil KA. Isolation of total aerobic and pathogenic bacteria from table eggs and its contents. Food Appl Biosci J 2015; 3(1): 1-9.

9. Collee JG, Fraser AG, Marimon B, Simmons A. Test for the identification of bacteria. In: Collee JG, Miles RS, Watt B (eds). Mackie McCartney Practical Medical Microbiology. $14^{\text {th }}$ edn. New York: Churchill Livingstone, 1996: 132-149.

10. Baur AW, Kirby WMM, Sherris JC, Turck M. Antibiotic susceptibility testing by a standardized single dose method. Am J Clin Patho 1966; 45: 493-496.

11. CLSI (Clinical and Laboratory Standard Institute). Performance standards for antimicrobial disc susceptibility testing; Twenty-first informational supplement. CLSI document M100-S21. Wayne, PA: CLSI; 2011.

12. CLSI (Clinical and Laboratory Standard Institute). Performance standards for antimicrobial disc susceptibility testing; $20^{\text {th }}$ informational supplement. CLSI document M100-S20. Wayne, PA: CLSI; 2010.

13. Foley SL, Nayak R, Irene BH, Timothy JJ, Han J. Population dynamics of Salmonella enterica serotypes in commercial egg and poultry production. Appl Environ Microbiol 2011; 77(13): 4273-4279.

14. De Reu K, Grijspeerdt K, Heyndrickx M. Bacterial eggshell contamination in conventional cages, furnished cages and aviary housing systems for laying hens. Br Poult Sci 2005; 46: 149-155.

15. De Reu K, Messens W, Heyndrickk M, Rodenburg TB, Herman L. Bacterial contamination of table eggs and the influence of housing systems. Int Poult Sci J 2008; 64: $6-19$.

16. Arthur CT, Osei-Somuah A. Sources of microbial contamination in smoked anchovies. Sci Technol 2001; 45: 29 .

17. Salihu MD, Garba B, Isah Y. Evaluation of microbial contents of table eggs at retail outlets in Sokoto metropolis, Nigeria. Sokoto J Vet Sci 2015; 13(1): 22-28.

18. Nazer AHK, Dadras H, Eskandari S. Aerobic bacteria isolated from eggs and day-old chicks and their antibacterial resistance in Shiraz, Iran. Iranian J Vet Res 2006; 7(2): 15-17. 